\title{
Growth inhibitory response and ultrastructural modification of oral-associated candidal reference strains (ATCC) by Piper betle L. extract
}

\begin{abstract}
Mohd-Al-Faisal Nordin ${ }^{1}$, Wan Himratul-Aznita Wan Harun ${ }^{1}$, Fathilah Abdul Razak ${ }^{1}$ and Md Yusoff Musa ${ }^{2}$
Candida species have been associated with the emergence of strains resistant to selected antifungal agents. Plant products have been used traditionally as alternative medicine to ease mucosal fungal infections. This study aimed to investigate the effects of Piper betle extract on the growth profile and the ultrastructure of commonly isolated oral candidal cells. The major component of $P$. betle was identified using liquid chromatography-mass spectrophotometry (LC-MS/MS). Seven ATCC control strains of Candida species were cultured in yeast peptone dextrose broth under four different growth environments: (i) in the absence of $P$. betle extract; and in the presence of $P$. betle extract at respective concentrations of (ii) $1 \mathrm{mg} \cdot \mathrm{mL}^{-1}$; (iii) $3 \mathrm{mg} \cdot \mathrm{mL}^{-1}$; and (iv) $6 \mathrm{mg} \cdot \mathrm{mL}^{-1}$. The growth inhibitory responses of the candidal cells were determined based on changes in the specific growth rates $(\mu)$. Scanning electron microscopy (SEM) was used to observe any ultrastructural alterations in the candida colonies. LC-MS/MS was performed to validate the presence of bioactive compounds in the extract. Following treatment, it was observed that the $\mu$-values of the treated cells were significantly different than those of the untreated cells $(P<0.05)$, indicating the fungistatic properties of the $P$. betle extract. The candidal population was also reduced from an average of $13.44 \times 10^{6}$ to $1.78 \times 10^{6}$ viable cell counts (CFU) $\mathrm{mL}^{-1}$. SEM examination exhibited physical damage and considerable morphological alterations of the treated cells. The compound profile from LC-MS/MS indicated the presence of hydroxybenzoic acid, chavibetol and hydroxychavicol in $P$. betle extract. The effects of $P$. betle on candida cells could potentiate its antifungal activity.
\end{abstract}

International Journal of Oral Science (2014) 6, 15-21; doi:10.1038/ijos.2013.97; published 10 January 2014

Keywords: antifungal activity; Candida; cell morphology; growth inhibitory effect; Piper betle L.

\section{INTRODUCTION}

Candida species represent a component of the normal flora in the oral cavity. However, under certain favorable conditions, these species can become opportunistic and cause infections in the oral cavity of immunocompromised hosts. This process occurs when there is a change in the ecological balance within the oral cavity that favors Candida over other microorganisms. Candida albicans has often been reported as the predominant species associated with superficial and systemic fungal infections. ${ }^{1}$ Of late, however, the prevalence of C. albicans has surpassed by the emergence of non-Candida albicans Candida species, ${ }^{2-4}$ and increased prescription of antifungal agents ${ }^{5}$ has been suggested to be a contributing factor. The increased number of compromised patients with common endocrine disorders such as diabetes mellitus, ${ }^{6}$ with malnutrition and with smoking habits, ${ }^{7}$ has been identified to be primarily responsible for the development of candidal infections. The wearing of dentures has also resulted in profound alterations in the normal oral flora, providing an opportunity for candida to colonize the underlying mucosa. ${ }^{8}$

The normal carriage rate of Candida in the oral cavity varies from $2 \%$ to $71 \%,{ }^{9}$ but can reach $100 \%$ in medically compromised patients and those on broad-spectrum antibacterial agents. ${ }^{10}$ Seven species of Candida have been identified in the oral cavity, and among these, C. albicans has been reported as the most prevalent pathogen in both mucosal and systemic fungal infections, ${ }^{11}$ while C. glabrata is the second or third most isolated pathogen in patients with oral candidosis. ${ }^{12}$ Candida possesses a multitude of virulence factors, and a key attribute to its virulence is its adaptability for growth. Thus, an understanding of the physiological growth process of the cells could better explain and support the sustainability of cells growing under unfavorable growth conditions.

Natural products as traditional remedies are in great demand, as they are perceived to have minimal side effect on humans. ${ }^{13}$ Malaysia is well known for its diverse possession of flora and fauna. Piper betle L. is a tropical creeper plant belonging to the pepper family. Decoctions prepared from the leaves are used to relieve coughing and asthma and to help in the treatment of halitosis, joint pain and itchiness. ${ }^{14}$ It is also popular as an antiseptic that is commonly applied on wounds and lesions for its healing effects. ${ }^{15}$ The extract of $P$. betle leaves has been reported to possess anti-oxidative, ${ }^{16}$ anti-inflammatory, antibacterial and antifungal activities. ${ }^{17-19}$ The minimal inhibitory concentration 
and minimal fungicidal concentration of $P$. betle extract against candidal species were reported to be within the range of 12.5$25.0 \mathrm{mg} \cdot \mathrm{mL}^{-1} \cdot{ }^{19}$ This study aimed to investigate the effects of $P$. betle extract on the growth profiles and ultrastructures of seven ATCC control strains of commonly isolated Candida species that have been associated with the oral cavity. The data obtained were analyzed to validate the antifungal effects of $P$. betle extract on these strains. Major components of $P$. betle were identified using liquid chromatographymass spectrophotometry (LC-MS/MS). Findings from the study could provide better understanding of the antifungal effects of the extract on the physiological growth processes of oral candidal strains and the morphology of colonies.

\section{MATERIALS AND METHODS}

\section{Plant collection and extract preparation}

Fresh leaves of $P$. betle were collected from a local farm in Selangor, Malaysia. The specimens were scientifically identified by a botanist from the Institute of Biological Science, Faculty of Science, University of Malaya. The voucher specimen was deposited at the Herbarium of Rimba Ilmu, University of Malaya, under reference number KLU 046620. Crude aqueous extract of the specimen was prepared according to Himratul-Aznita et al. ${ }^{19}$ The specimen was washed and oven-dried at $60-65{ }^{\circ} \mathrm{C}$ for 2 days. The dried specimen was homogenized in distilled water at a ratio of specimen to water of $1: 10$. The homogenate was heated at a high temperature and concentrated to one-third of the original volume. The concentrate was filtered through filter paper (Whatman No. 1) before it was further heated to a final volume of $100 \mathrm{~mL}$. The decoction was then concentrated overnight by freeze-drying (FDU-1200; EYELA, Tokyo, Japan). The powder obtained was kept in sterile Falcon polypropylene conical bottom tubes and was stored at $4{ }^{\circ} \mathrm{C}$. Prior to use, a stock solution of the extract was prepared in sterile distilled water at a concentration of $200 \mathrm{mg} \cdot \mathrm{mL}^{-1}$. Following centrifugation (Jouan A14; Jouan, Saint Herblain, France) for $10 \mathrm{~min}$ at $8000 \mathrm{~g}$, the stock was then diluted to the concentrations required for the experiment. The extract was sterilized by filtration using a $0.2 \mu \mathrm{m}$ nylon syringe filter (Millipore, Billerica, MA, USA).

\section{Microbial strains}

Seven strains of oral Candida, which included Candida albicans ATCC 14053, Candida dubliniensis ATCC MYA-2975, Candida glabrata ATCC 90030, Candida krusei ATCC 14243, Candida lusitaniae ATCC 64125, Candida parapsilosis ATCC 22019 and Candida tropicalis ATCC 13803, were purchased from the American Type Culture Collection (ATCC, Manassas, VA, USA) for use in the study. Yeast peptone dextrose (YPD) broth (BD Difco, Sparks, MD, USA) was used to revive the cultures.

\section{Preparation of standard candidal suspension}

Stocks of the Candida strains were revived in $5 \mathrm{~mL}$ of YPD broth and were allowed to propagate overnight at $37{ }^{\circ} \mathrm{C}$ in a horizontal incubator shaker. The cells were then harvested by centrifugation at $8000 \mathrm{~g}\left(10{ }^{\circ} \mathrm{C}\right)$ for $5 \mathrm{~min}$. The supernatant was discarded, while the pellet was washed twice with sterile saline $\left(8.5 \mathrm{~g} \cdot \mathrm{L}^{-1}\right)$. The pellet was resuspended in $40 \mathrm{~mL}$ of YPD broth, and the concentration of the suspension was adjusted to an optical density of 0.144 at $550 \mathrm{~nm}$. At this optical density, the cell population was equivalent $1 \times 10^{6}$ cells per $\mathrm{mL}$ or to $\# 0.5 \mathrm{McF}$ arland standard.

\section{Growth profiles of Candida species}

Five milliliters of candidal suspension $\left(\times 10^{6}\right.$ cells per $\left.\mathrm{mL}\right)$ were dispensed into three sterile conical flasks, each containing $40 \mathrm{~mL}$ of YPD broth. Sterile distilled water $(5 \mathrm{~mL})$ was added to yield a total volume of $50 \mathrm{~mL}$ in each flask. The flasks were incubated at $37{ }^{\circ} \mathrm{C}$ (C. parapsilosis at $35{ }^{\circ} \mathrm{C}$ ) for $18 \mathrm{~h}$ in a shaking water bath to agitate the suspension continuously. Spectrophotometric assay, ${ }^{20}$ which is based on continuous monitoring of changes in the optical density of cell growth, was employed. Cell growth was measured periodically at one-hour intervals over a period of $18 \mathrm{~h}$ at an optical absorbance of $550 \mathrm{~nm}$. The growth of different candidal species could be distinguished by measuring the changes of specific growth rates $(\mu)$, using the equation previously described: ${ }^{21-22}$

$$
\mu=\frac{\ln \left(N_{t} / N_{0}\right)}{t_{2}-t_{1}}
$$

where $N_{t}$ represented the number of cells at log phase, $N_{0}$ represented the number of cells at zero time, $t_{2}$ was the time taken to reach plateau and $t_{1}$ zero was the time when the cells entered the log phase. The $\mu$ values were distinguished from the exponential phase, during which the cells appearing per unit time were proportional to the present population. The growth of seven candidal species was also determined based on the viable cell counts (CFUs), estimated at 2, 6, 10, 14 and $16 \mathrm{~h}$ intervals. The cell suspension was first diluted by serial dilution in a nontoxic diluent (e.g., phosphate-buffered saline, $\mathrm{pH}$ 7.2-7.4) before plating. To serve as a positive control, chlorhexidine $\left(1.2 \mathrm{~g} \cdot \mathrm{L}^{-1}\right)$-containing mouth rinse was used in place of the extract.

\section{Growth inhibitory activity of $P$. betle extract}

$P$. betle extract was prepared into stocks of 10,30 and $60 \mathrm{mg} \cdot \mathrm{mL}^{-1}$. Five milliliters of each stock concentration was dispensed into sterile conical flasks containing $40 \mathrm{~mL}$ of YPD broth, followed by $5 \mathrm{~mL}$ of the respective candidal suspension $\left(1 \times 10^{6}\right.$ cells per $\left.\mathrm{mL}\right)$ to yield final concentrations of 1,3 and $6 \mathrm{mg} \cdot \mathrm{mL}^{-1}$ of the extract. In a similar manner, the culture flasks were placed in a shaking water bath at $37{ }^{\circ} \mathrm{C}$ (C. parapsilosis was incubated at $35^{\circ} \mathrm{C}$ ), and the growth of cells in the presence of the extract was measured periodically at $1-\mathrm{h}$ intervals over a period of $18 \mathrm{~h}$. Changes in specific growth rate $(\mu)$ were calculated, and the findings were compared with those of the standard. The inhibitory effect of the extract was also determined, based on viable cell counts.

\section{Scanning electron microscope examination}

Fresh candidal suspension was cultured on YPD agar, and the colonies were allowed to grow for $24 \mathrm{~h}$. Using a sterile blade, the agar was cut to approximately $1 \mathrm{~cm} \times 1 \mathrm{~cm}$ and was transferred into a sterile vial to be treated with the $6 \mathrm{mg} \cdot \mathrm{mL}^{-1}$ extract for $4 \mathrm{~h}$. Prior to scanning electron microscope (SEM) processing, the samples were prefixed with a $4 \%$ glutaraldehyde solution overnight at $4{ }^{\circ} \mathrm{C}$. The samples were then washed with $0.1 \mathrm{~mol} \cdot \mathrm{L}^{-1}$ sodium cacodylate buffer $(\mathrm{pH} 7.4)$, followed by fixation in $2 \%$ osmium tetroxide in the buffer solution overnight. The next day, the samples were gently washed in distilled water twice for 15 min and were dehydrated in an ascending series of ethanol concentrations $(10 \%, 20 \%, 30 \%, 40 \%, 50 \%, 60 \%, 70 \%, 80 \%, 90 \%$ and $95 \%)$ for $15 \mathrm{~min}$ each. The samples were then dehydrated twice in $100 \%$ ethanol for $15 \mathrm{~min}$ and subsequently were dehydrated in an ethanolacetone mixture at ratios of $3: 1,1: 1$ and $1: 3$ for 15 min each. Then, the samples were treated three times with pure acetone for $15 \mathrm{~min}$. The samples were processed for critical point drying (Balzers CPD 030; BalTec AG, Balzers, Liechtenstein) for $2 \mathrm{~h}$ in liquid $\mathrm{CO}_{2}$ under 95 bar pressure. Finally, the samples were gold-coated under low pressure with an ion sputter coater (JOEL JFC1100; JEOL, Tokyo, Japan). Any physical changes in the morphology of the candidal cells were observed with a scanning electron microscope. 
Liquid chromatography-mass spectrophotometry analysis

Liquid chromatography-mass spectrophotometry (LC-MS/MS) analysis was performed with a Perkin-Elmer FX 15 UHPLC (Flexar autosampler, Flexar binary pump, Flexar column oven, Flexar degasser; PerkinElmer, Waltham, MA, USA) coupled to an AB SCIEX 3200QTrap MS/MS system, in the electrospray ionization negative mode. Ten microliters of the sample were injected onto a Phenomenex Aqua column $\mathrm{C}_{18}$ (50 $\mathrm{mm} \times 2.0 \mathrm{~mm} \times 5 \mu \mathrm{m}$ particle size). The mobile phases, consisting of solvent $\mathrm{A}$ (water with $0.1 \%$ formic acid and $5 \mathrm{mmol} \cdot \mathrm{L}^{-1}$ ammonium formate) and solvent B (acetonitrile with $0.1 \%$ formic acid and $5 \mathrm{mmol} \cdot \mathrm{L}^{-1}$ ammonium formate), were used in gradient mode with the following conditions (time/concentration) for B: $0.0 \mathrm{~min} / 5 \% ; 8.0$ $\mathrm{min} / 90 \% ; 10.0 \mathrm{~min} / 90 \% ; 10.1 \mathrm{~min} / 5 \% ; 15.0 \mathrm{~min} / 5 \%$; and with a flow rate between 0.25 and $0.4 \mathrm{~mL} \cdot \mathrm{min}^{-1}$. Rapid screening was performed at $15 \mathrm{~min}$ of run time, and the scan range of MS-MS was $m / z 50-260$. The extract was diluted five times with water and was filtered with a $0.2 \mu \mathrm{m}$ nylon filter prior to analysis. The spectrum of the unknown component was compared with the spectra of the known components stored in the MS/MS library. The name and molecular weight of the components of the extract were ascertained.

\section{Statistical analysis}

All of the data obtained were computed and are expressed as the mean \pm standard deviation (s.d.) from three independent experiments performed in triplicate $(n=9)$. Statistical analysis was performed using SPSS (Statistical Package for the Social Sciences) software (version 17.0; SPSS, Chicago, IL, USA). An independent $t$-test was used to compare the significant differences between controls (untreated) and $P$. betle-treated samples for each individual candidal species. One-way analysis of variance was applied to compare the specific growth rates $(\mu)$ of the seven Candida species upon exposure to $P$. betle extract. A $P$ value $<0.05$ was considered statistically significant.

\section{RESULTS}

Normal growth curves of Candida strains

The normal growth curves of all seven candidal strains were cultured under normal, untreated growth conditions. The curves were all sigmoidal, with clear exhibition of the lag, log and stationary phases. Varying durations of the lag and log phases were observed among the different species. In general, approximately $5-7 \mathrm{~h}$ was required by the cells to adapt to the normal growth environment before they were ready to proliferate and enter the log phase. C. tropicalis showed the highest growth rates $(0.319 \pm 0.002) \mathrm{h}^{-1}$ indicating high proliferation. The others were in the range of $(0.141 \pm 0.001)-(0.265 \pm 0.005) \mathrm{h}^{-1}$. Based on the enumeration of CFUs, it was shown that the population of candidal species increased gradually from $1.00 \times 10^{5}$ to $1.61 \times 10^{10} \mathrm{CFU} \cdot \mathrm{mL}^{-1}$ over $18 \mathrm{~h}$ of incubation (Figure 1).

\section{Growth curves of Candida strains following treatment with P. betle extract}

The patterns of the growth curves of all seven candidal strains were altered and showed deviations from the normal sigmoidal pattern following treatment with $P$. betle extract. Extension of the lag phases and suppression of cell growth were indicated by the reduction in $\mu$ values (Table 1). The growth suppression effect of the extract was found to be concentration-dependent.

At $1 \mathrm{mg} \cdot \mathrm{mL}^{-1}$, the $\mu$-values of Candida species were mostly reduced by a range of $15 \%-42 \%$. The reduction of $C$. parapsilosis, however, was not significant $(P=0.537)$. Exposing the candidal cells to $3 \mathrm{mg} \cdot \mathrm{mL}^{-1}$ of the extract drastically reduced the $\mu$-values of all of the Candida species to almost half of the untreated cells. C. dubliniensis was considered the most susceptible to the extract (97.61\%), followed by C. Iusitaniae (88.68\%) and C. albicans (88.21\%). The $\mu$-value reductions of the four others were comparatively lower, in the range of $48 \%-$ $71 \%$. The $\mu$-values of all of the species were more than $90 \%$ reduced at $6 \mathrm{mg} \cdot \mathrm{mL}^{-1}$ of $P$. betle $(P<0.05)$. Except for C. krusei $(P=0.513)$, significant reductions in the specific growth rates of all of the strains were observed at $6 \mathrm{mg} \cdot \mathrm{mL}^{-1}(P<0.05)$. Deviations in the $\mu$-values resulted in extension of the lag and log phases. Based on CFU enumeration, the populations of all of the candidal species also showed reductions of an average of $\left(13.44 \times 10^{6}\right)-\left(1.78 \times 10^{6}\right) \mathrm{CFU} \cdot \mathrm{mL}^{-1}$ (Figure 1).

\section{Morphology of Candida strains following treatment with P. betle extract}

Treated samples of Candida were observed by SEM to investigate any physical changes in the appearance of the cells. Figure 2 shows the SEM images of the untreated and P. betle-treated candidal species. The

Table 1 Changes in the specific growth rates $(\mu)$ of the seven candidal species that was grown in the absence (untreated) and presence of Piper betle extract

\begin{tabular}{|c|c|c|c|c|c|}
\hline \multirow[b]{2}{*}{ Candida species } & \multirow[b]{2}{*}{ Specific growth rates $(\mu)$} & \multirow[b]{2}{*}{ Untreated } & \multicolumn{3}{|c|}{ Piper betle extract treated } \\
\hline & & & $1 \mathrm{mg} \cdot \mathrm{mL}^{-1}$ & $3 \mathrm{mg} \cdot \mathrm{mL}^{-1}$ & $6 \mathrm{mg} \cdot \mathrm{mL}^{-1}$ \\
\hline \multirow[t]{2}{*}{ C. albicans ATCC 14053} & $\mu / \mathrm{h}^{-1}$ & $0.263 \pm 0.011$ & $0.152 \pm 0.008$ & $0.031 \pm 0.005$ & $0.005 \pm 0.005$ \\
\hline & Reduction in $\mu / \%$ & - & 42.21 & 88.21 & 98.10 \\
\hline \multirow[t]{2}{*}{ C. dubliniensis ATCC MYA-2975 } & $\mu / \mathrm{h}^{-1}$ & $0.251 \pm 0.010$ & $0.183 \pm 0.014$ & $0.006 \pm 0.004$ & $0.004 \pm 0.003$ \\
\hline & Reduction in $\mu / \%$ & - & 27.09 & 97.61 & 98.41 \\
\hline \multirow{2}{*}{ C. glabrata ATCC 90030} & $\mu / \mathrm{h}^{-1}$ & $0.263 \pm 0.004$ & $0.174 \pm 0.008$ & $0.099 \pm 0.012$ & $0.011 \pm 0.006$ \\
\hline & Reduction in $\mu / \%$ & - & 33.84 & 62.36 & 95.82 \\
\hline \multirow[t]{2}{*}{ C. krusei ATCC 14243} & $\mu / \mathrm{h}^{-1}$ & $0.251 \pm 0.006$ & $0.151 \pm 0.006$ & $0.077 \pm 0.007$ & $0.027 \pm 0.005$ \\
\hline & Reduction in $\mu / \%$ & - & 39.84 & 69.32 & 89.24 \\
\hline \multirow[t]{2}{*}{ C. Iusitaniae ATCC 64125} & $\mu / \mathrm{h}^{-1}$ & $0.265 \pm 0.005$ & $0.180 \pm 0.009$ & $0.030 \pm 0.004$ & $0.012 \pm 0.003$ \\
\hline & Reduction in $\mu / \%$ & - & 32.08 & 88.68 & 95.47 \\
\hline \multirow[t]{2}{*}{ C. parapsilosis ATCC 22019} & $\mu / \mathrm{h}^{-1}$ & $0.141 \pm 0.001$ & $0.139 \pm 0.002$ & $0.074 \pm 0.004$ & $0.010 \pm 0.003$ \\
\hline & Reduction in $\mu / \%$ & - & 1.42 & 47.52 & 92.91 \\
\hline \multirow[t]{2}{*}{ C. tropicalis ATCC 13803} & $\mu / \mathrm{h}^{-1}$ & $0.319 \pm 0.002$ & $0.271 \pm 0.004$ & $0.109 \pm 0.004$ & $0.008 \pm 0.007$ \\
\hline & Reduction in $\mu / \%$ & - & 15.05 & 65.83 & 97.49 \\
\hline
\end{tabular}

ATCC, American Type Culture Collection.

Values were obtained from spectrophotometric assay and expressed as mean \pm standard deviation of three independent experiments performed in triplicate ( $n=9$ ). 

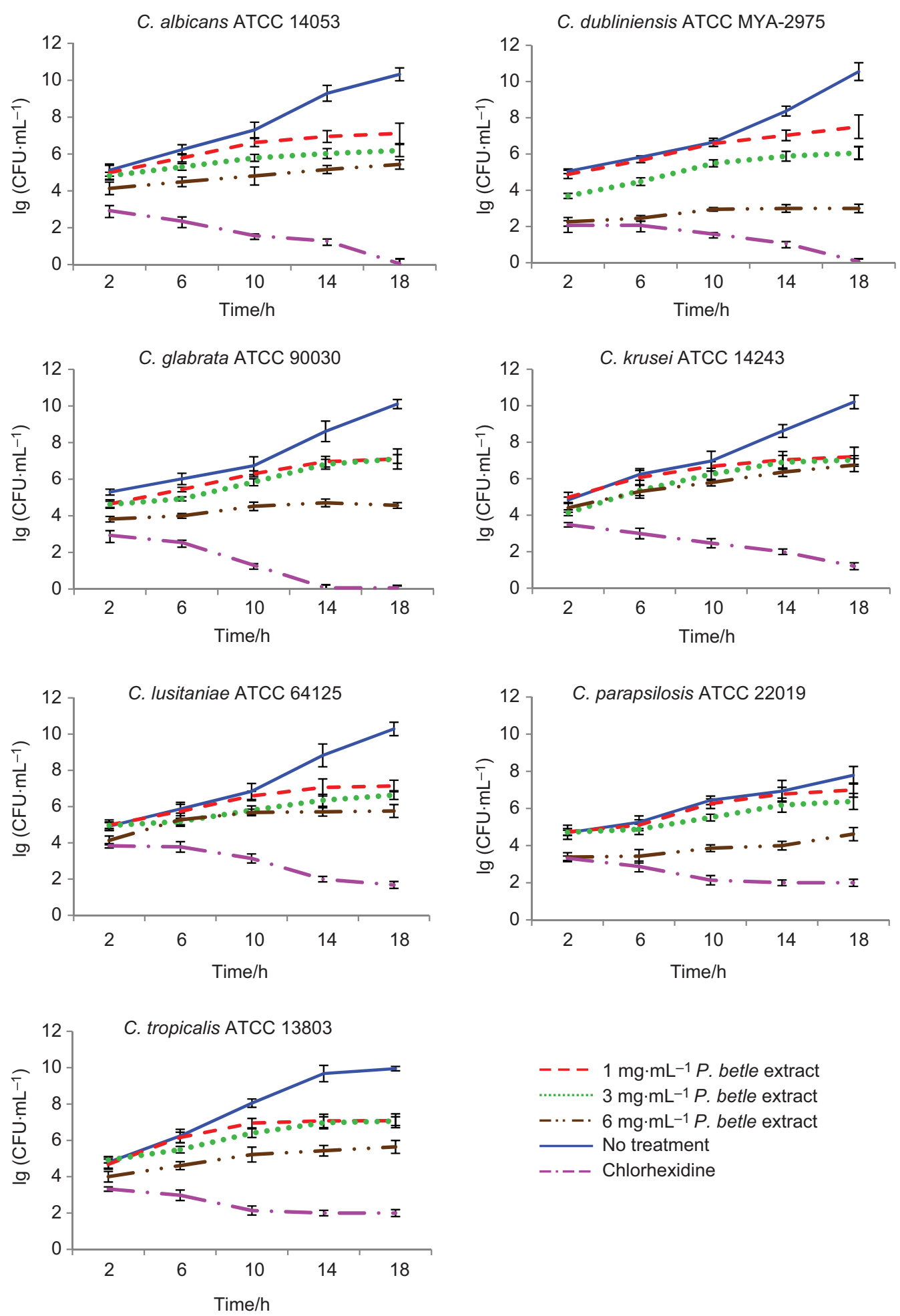

Figure 1 The population of candidal species under treatment with $P$. betle extract at 1,3 and $6 \mathrm{mg} \cdot \mathrm{mL}^{-1}$. Chlorhexidine was used as a reference. The data are expressed as the mean \pm standard deviation of three independent experiments performed in triplicate $(n=59)$.

non-treated cells were entirely intact, and they had attained optimum cell sizes within the range of $(3.13 \mu \mathrm{m} \times 2.33 \mu \mathrm{m})-(6.65 \mu \mathrm{m} \times 1.95 \mu \mathrm{m})$ (Table 2). These non-treated cells were smooth-surfaced and rounded, and some were elongated in their well-developed structures. It was observed that the cells were in the active dividing state, as the interconnecting processes and buds were present.
Some physical changes and morphological alterations in the candidal cells were observed following treatment with $P$. betle extract. It was found that the cells were slightly smaller. Based on the independent $t$-test, the mean lengths of $C$. albicans, $C$. glabrata and C. Iusitaniae were significantly different $(P<0.05)$ between the untreated and $P$. betle-treated cells. The widths of all of the candidal 

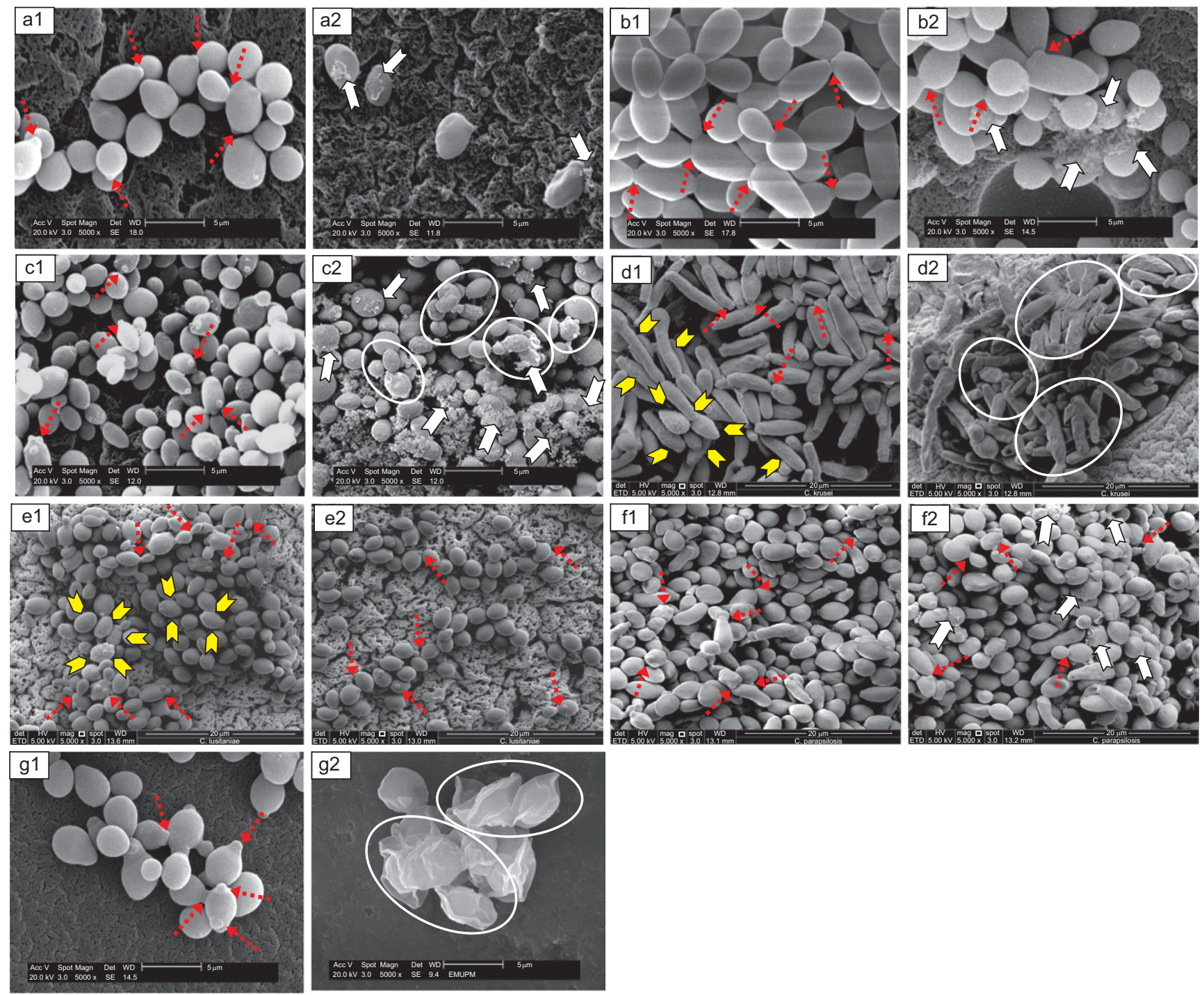

Figure 2 Composite micrographs illustrating the morphological changes of seven Candida species treated with $P$. betle extract, compared to untreated candidal cells. (a) C. albicans; (b) C. dubliniensis; (c) C. glabrata; (d) C. krusei; (e) C. Iusitaniae; (f) C. parapsilosis; (g) C. tropicalis. 1, Control, untreated; 2, treated with $P$. betle extract. Magnification: $\times 5000 . \Rightarrow$, Dense deposits; $\ldots . . . \rightarrow$, buds and dividing state; $\bigcirc$, decomposition and shrunk; $\square$, punctates.

cells, however, were not significant, except for that of C. albicans $(P=0.011)$ (Table 2). Despite the minimal changes in the sizes of the cells, alterations of their morphology might be an indication of the inhibitory effects of the extract, which in one way or another affected the growth profile of Candida cells. Some candidal cells shrank and became flaccid due to the decomposition of the cell

Table 2 Deviations in the sizes of candidal cells following treatment of Piper betle extract

\begin{tabular}{|c|c|c|c|c|}
\hline \multirow[b]{2}{*}{ Candida species } & \multicolumn{2}{|c|}{ Normal } & \multicolumn{2}{|c|}{ P. betle extract treated } \\
\hline & Length/ $\mu \mathrm{m}$ & 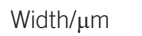 & Length/ $\mu \mathrm{m}$ & 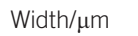 \\
\hline C. albicans ATCC 14053 & $3.93 \pm 0.30$ & $3.07 \pm 0.15$ & $3.20 \pm 0.51^{a}$ & $2.73 \pm 0.19^{a}$ \\
\hline C. dubliniensis ATCC MYA-2975 & $4.11 \pm 0.48$ & $2.40 \pm 0.15$ & $3.57 \pm 0.47$ & $2.43 \pm 0.13$ \\
\hline C. glabrata ATCC 90030 & $3.13 \pm 0.39$ & $2.33 \pm 0.39$ & $2.43 \pm 0.23^{a}$ & $1.87 \pm 0.45$ \\
\hline C. krusei ATCC 14243 & $6.65 \pm 0.52$ & $1.95 \pm 0.16$ & $6.00 \pm 0.71$ & $1.85 \pm 0.48$ \\
\hline C. Iusitaniae ATCC 64125 & $3.80 \pm 0.44$ & $2.56 \pm 0.25$ & $3.16 \pm 0.24^{\mathrm{a}}$ & $2.40 \pm 0.21$ \\
\hline C. parapsilosis ATCC 22019 & $4.56 \pm 0.34$ & $2.36 \pm 0.28$ & $4.04 \pm 0.63$ & $2.32 \pm 0.25$ \\
\hline C. tropicalis ATCC 13803 & $3.80 \pm 0.51$ & $2.80 \pm 0.18$ & $3.77 \pm 0.59$ & $2.90 \pm 0.33$ \\
\hline
\end{tabular}

ATCC, American Type Culture Collection.

a $P<0.05$ comparing to the untreated (normal) candidal cell sizes.

Values are expressed as mean \pm standard deviation of nine determinations $(n=9)$. 
Table 3 Tentative identification of major compounds in crude extract of betel leaves (Piper betle) by LC-MS/MS

\begin{tabular}{lclcc}
\hline Peak & $\mathrm{R}_{\mathrm{t}} / \mathrm{min}$ & Tentative names of compounds & $\mathrm{MW}$ & $\mathrm{m} / \mathrm{z}$ \\
\hline 1 & 3.49 & Hydroxybenzoic acid $\left(\mathrm{C}_{7} \mathrm{H}_{6} \mathrm{O}_{3}\right)$ & 138 & 137.0 \\
2 & 4.27 & Chavibetol $\left(\mathrm{C}_{10} \mathrm{H}_{12} \mathrm{O}_{2}\right)$ & 164 & 163.0 \\
3 & 5.47 & Hydroxychavicol $\left(\mathrm{C}_{9} \mathrm{H}_{10} \mathrm{O}_{2}\right)$ & 150 & 149.0 \\
\hline
\end{tabular}

LC-MS/MS, liquid chromatography-mass spectrophotometry; MW, molecular weight; $R_{t}$, retention time; $\mathrm{m} / \mathrm{z}$, mass-to-charge ratio.

wall. Among the treated candidal cells, deposition of heavy, meshlike extracellular matrix was observed, which resulted in a fluffy appearance around the cells (Figure 2).

\section{Identification of the main constituents of Piper betle}

The chromatogram of LC-MS/MS and the associated analytical data showed that the main constituents of $P$. betle leaf extract corresponded to hydroxychavicol, chavibetol and hydroxybenzoic acid. It was clearly demonstrated that hydroxychavicol was a predominant component in crude $P$. betle extract (Table 3 ).

\section{DISCUSSION}

The selection of the ATCC reference strains C. albicans, C. dubliniensis, C. glabrata, C. krusei, C. lusitaniae, C. parapsilosis and C. tropicalis was based on various reports of the prevalence of Candida species in the oral cavity. ${ }^{2,10,23-24}$ Although the reference strains were isolated originally from blood, similar strains have also been reported as present in the oral cavity. ${ }^{25-27}$

It was found that $P$. betle extract exhibited varying degrees of growth inhibitory effects on species of Candida without displaying cytotoxic effects on normal cell lines. ${ }^{28}$ C. dubliniensis appeared to be the most susceptible strain to $P$. betle, compared to the others. Disruption of the normal physiological growth of candidal cells was indicated by the deviation of the growth curves from the normal pattern. Upon the addition of $P$. betle extract to the growth environment, the log phase of Candida species was reduced and shifted to the right. The presence of a higher concentration of $P$. betle extract affected the specific growth rates of seven candidal species. Therefore, this extract demonstrated fungistatic activity towards seven candidal species and successfully suppressed the cells, causing them to become dormant and unable to proliferate actively.

Those cells grown in the presence of $P$. betle extract could have experienced environmental stress, which might have influenced their ability to use nutrients efficiently, thereby slowing their growth. In addition, their metabolisms might have been deactivated while waiting for the environment to revert to the normal condition. This effect was previously observed for Candida species when growth curves based on capacitance were obtained. ${ }^{29}$ It was observed that the fungistatic effect of the extract was concentration-dependent. The higher the concentration was, the more the critical turbidity was delayed. resulting in a longer lag phase. Fathilah et al. ${ }^{18}$ reported that the early settlers of dental plaque also experienced bacteriostatic effects when treated with $P$. betle extract, indicating that $P$. betle extract has a significant antimicrobial activity against a broad spectrum of oral microorganisms.

SEM images demonstrated that there were alterations in the morphology of Candida cells following treatment with $P$. betle extract. Dense deposits were observed when a matrix was formed on the surface of the cells, as indicated by the arrows $(\Rightarrow)$ in Figure $2(a 2, b 2, c 2$ and $\mathrm{f} 2$ ). Some species were able to retain their structures and their buds while they were still in the actively dividing state, as indicated by the open arrows ( $\cdots \rightarrow)$ in Figure 2 (a1, b1-b2, c1, d1, e1-e2, f1-f2 and g1). The destructive effects of the extract on the cells might have been minimal, but there was a possibility of certain cell wall constituents that were less firmly bound to the rigid glucan-chain network being lost during the extract treatment. As a result, the ions' and nutrients' uptake mechanisms, which normally occur on the cell surfaces, could have been restricted. Figure 2 (c2, d2 and g2) clearly demonstrates that the cells endured decomposition of the cell wall, some which shrank (circled; $\bigcirc$ ) and showed apparent loss of cell density. This finding explains the reduction in sizes of the treated cells relative to the untreated cells. In addition, the punctate appearance (arrow head; $\Sigma$ ), which was observed to be randomly positioned on the surface of untreated C. krusei $^{30}$ and C. lusitaniae, disappeared following treatment with the extract, which illustrated the direct effects of $P$. betle extract on the candidal cell walls. Similar findings were also reported by Nakamura et al. ${ }^{31}$ with regard to the effects on the morphology and ultrastructure of yeasts.

The extract of $P$. betle leaf has been reported to possess various chemical constituents, ${ }^{32-34}$ that could be isolated from the solvent extract. In the present study, hydroxychavicol, chavibetol and hydroxybenzoic acid were among the bioactive constituents found present in the aqueous extract of $P$. betle. They were similar to the types that were previously identified as present in the other solvent extracts. Hydroxychavicol, which is a phenol, was the major compound in $P$. betle extract. In the presence of hydroxychavicol, the extract might have the tendency to act as an antioxidant and a chemopreventive agent, and it might possess anticarcinogenic activities. ${ }^{35}$ There have been several previous studies reporting the antibacterial and antifungal activities of hydroxychavicol. ${ }^{36}$ Chavibetol, an isomer of eugenol, was regarded as one of the most active components against Grampositive and Gram-negative bacteria. ${ }^{37}$ Hydroxybenzoic acid is a phenolic derivative of benzoic acid, and it has also been reported to possess antifungal effects on the mycelia growth of Eutypa lata. ${ }^{38}$ The antimicrobial action has been shown to be determined by more than one compound, ${ }^{39}$ which are responsible not only for the antimicrobial activity but also for the synergistic effect. The mechanism of action of these components is expected to be similar to those of other terpenes and phenolic compounds, which allow for the adherence of Candida to host tissue surfaces before it can penetrate to target sites. The distortion of wall components and the disruption of the cytoplasmic membrane cause coagulation of the cell contents, thus leading to a loss of structural integrity and of the ability of the membrane to act as a permeability barrier. ${ }^{40}$ These changes can be attributed to the fungistatic activity and affect the physiological functions of Candida. In addition, the extensive loss of the cell contents and the efflux of critical molecules and ions due to high concentrations of extract might initiate an autolytic process that results in cell death.

In conclusion, this study showed that betel leaf extract possessed potent fungistatic activity on Candida species. The suppression of cell growth and the alterations in morphology diminished the population of Candida and reduced the likelihood of its invading and colonizing the oral tissues. The presence of bioactive components in the crude aqueous extract of $P$. betle also suggests that betel leaves have the potential to be used as an antifungal agent in oral health care products in the future.

\section{ACKNOWLEDGEMENTS}

This study was financially supported by the High Impact Research Grants (H18001-00-C000017 and H-18001-00-C000015), the University of Malaya Grant (RG095/09HTM) and the Postgraduate Research Fund (PS160/2010B). The 
authors would like to express appreciation to the laboratory staff of the Department of Oral Biology and Biomedical Sciences, Faculty of Dentistry, University of Malaya, for its assistance during the course of this study.

1 Vazquez JA, Sobel JD. Mucosal candidiasis. Infect Dis Clin North Am 2002; 16(4) 793-820.

2 Fleming RV, Walsh TJ, Anaissie EJ. Emerging and less common fungal pathogens. Infect Dis Clin North Am 2002; 16(4): 915-933.

3 Resende JC, Franco GR, Rosa CA et al. Phenotypic and genotypic identification of Candida spp. isolated from hospitalized patients. Rev Iberoam Micol 2004; 21(1): 24-28.

4 Sánchez-Vargas LO, Ortiz-López NG, Villar M et al. Point prevalence, microbiology and antifungal susceptibility patterns of oral Candida isolates colonizing or infecting Mexican HIV/AIDS patients and healthy persons. Rev Iberoam Micol 2005; 22(2): 83-92.

5 Pfaller MA, Diekema DJ, Rinaldi MG et al. Results from the ARTEMIS DISK Global Antifungal Surveillance Study: 6.5 year analysis of susceptibilities of Candida and other yeast species to fluconazole and voriconazole by standardized disk diffusion testing. J Clin Microbiol 2005; 43(12): 5848-5859.

6 Tapper-Jones LM, Aldred MJ, Walker DM et al. Candidal infections and populations of Candida albicans in mouths of diabetics. J Clin Pathol 1981; 34(7): 706-711.

7 Kuc IM, Samaranayake LP, van Heyst EN. Oral health and microflora in an institutionalised elderly population in Canada. Int Dent J 1999; 49(1): 33-40.

8 Mizugai $\mathrm{H}$, Isogai E, Hirose $\mathrm{K}$ et al. Effect of denture wearing on occurrence of Candida species in the oral cavity. J App/ Res 2007; 7(3): 250-254.

9 Samanarayake LP, MacFarlane TW. Oral candidosis. London: Wright, 1990: 1-8, 66, 104-124.

10 Marsh PD, Martin MV. Oral microbiology. 5th ed. Edinburgh: Churchill Livingstone Elsevier, 2009: 24-44.

11 Pfaller MA, Diekema DT, Jones RN et al. Trends in antifungal susceptibility of Candida spp. isolated from pediatric and adult patients with bloodstream infections: SENTRY Antimicrobial Surveillance Program, 1997 to 2000. J Clin Microbiol 2002; 40(3): 852-856.

12 Fidel PL Jr, Vazquez JA, Sobel JD. Candida glabrata: review of epidemiology, pathogenesis and clinical disease with comparison to C. albicans. Clin Microbio Rev 1999; 12(1): 80-96.

13 Maghrani M, Zeggwagh NA, Haloui M et al. Acute diuretic effect of aqueous extract of Retama raetam in normal rats. J Ethnopharmacol 2005; 99: 31-35.

14 Ong HC, Nordiana M. Malay ethnomedico botany in Machang, Kelantan Malaysia. Fitoterapia 1999; 70: 502-513.

15 Keat EC, Razak SS, Fadil NM et al. The effect of Piper bete/ extract on the wound healing process in experimentally induced diabetic rats. Clin Ter 2010; 161(2): 117-120.

16 Choudhury D, Kale RK. Antioxidant and non-toxic properties of Piper bet/e leaf extract: in vitro and in vivo studies. Phytother Res 2002; 16(5): 461-466.

17 Nalina T, Rahim ZH. The crude aqueous extract of Piper bet/e L. and its antibacteria effect towards Streptococcus mutans. Am J Biotech Biochem 2007; 3(1): 10-15.

18 Fathilah AR, Rahim ZH, Othman Y et al. Bacteriostatic effect of Piper betle and Psidium guajava extracts on dental plaque bacteria. Pak J Biol Sci 2009; 12(6): 518-521.

19 Himratul-Aznita WH, Mohd-AI-Faisal N, Fathilah AR. Determination of the percentage inhibition of diameter growth (PIDG) of Piper bet/e crude aqueous extract against oral Candida species. J Med Plant Res 2011; 5(6): 878-884.

20 Meletiadis J, Meis JF, Mouton JW et al. Analysis of growth characteristic of filamentous fungi in different nutrient media. J Clin Microbiol 2001; 39(2): 478-484.
21 Gerhardt P, Murray RG, Costlow RN et al. Manual of methods for general bacteriology. Washington: American Society for Microbiology, 1981.

22 Cappuccino JG, Sherman N. Microbiology: a laboratory manual. 7th ed. Aurora: Pearson, 2005.

23 Krcmery V, Barnes AJ. Non-albicans Candida spp. causing fungaemia pathogenicity and antifungal resistance. J Hosp Infect 2002; 50(4): 243-260.

24 Gravina HG, de Morán EG, Zambrano 0 et al. Oral candidiasis in children and adolescents with cancer: identification of Candida spp. Med Oral Patol Oral Cir Bucal 2007; 12(6): 419-423.

25 Dronda F, Alonso-Sanz M, Laguna F et al. Mixed oropharyngeal candidiasis due to Candida albicans and non-albicans Candida strains in HIV-infected patients. Eur J Clin Microbiol Infect Dis 1996; 15(6): 446-452.

26 Madigan MT, Martinko JM. Brock biology of microorganisms. 11th ed. Upper Saddle River: Pearson Prentice Hall, 2006.

27 Bokor-Bratić Marija B. Oral candidiasis-adhesion of non-albicans Candida species. Zbornik Matice Srpske za Prirodne Nauke 2008; (114): 69-78.

28 Fathilah AR, Sujata R, Norhanom WA et al. Antiproliferative activity of aqueous extract of Piper betle L. and Psidium guajava L. on KB and HeLa cell lines. J Med Plant Res 2010; 4(11): 987-990.

29 Chang $\mathrm{HC}$, Chang JJ, Huang $\mathrm{AH}$ et al. Evaluation of a capacitance method for direct antifungal susceptibility testing of yeasts in positive blood cultures. J Clin Microbiol 2000; 38(3): 971-976.

30 Hafiz A, Fathilah AR, Yusoff MM et al. Effect of phenotypic switching on the biological properties and susceptibility to chlorhexidine in Candida krusei ATCC 14243. FEMS Yeast Res 2012; 12(3): 351-358.

31 Nakamura CV, Ishida K, Faccin LC et al. In vitro activity of essential oil from Ocimum grastissimum L. against four Candida species. Res Microbiol 2004; 155(7): 579 586.

32 Rimando AM. Studies on the constituents of Philippines P. bet/e leaves. Arch Pharmacal Res 1986; 9(2): 93-97.

33 Dormans HJD, Deans SG. Antimicrobial agents from plants: antibacterial activity of plant volatile oil. J Appl Microbiol 2002; 88(2): 308-316.

34 Pauli A. Antimicrobial properties of essential oil constituents. Int J Aromather 2001; 11(3): 126-133.

35 Sharma S, Khan IA, Ali I et al. Evaluation of the antimicrobial, antioxidant and antiinflammatory activities of hydroxychavicol for its potential use as an oral care agent. Antimicrob Agents Chemother 2009; 53(1): 216-222.

36 Ali I, Khan FG, Suri KA et al. In vitro antifungal activity of hydroxychavicol isolated from Piper betle L. Ann Clin Microbiol Antimicrob 2010; 9: 7-15.

37 Friedman M, Henika PR, Mandrell RE. Bactericidal activities of plant essential oils and some of their isolated constituents against Campylobacter jejuni, Escherichia coli, Listeria monocytogenes and Salmonella enteric. J Food Prot 2002; 65(10): 1545-1560.

38 Amborabé BE, Fleurat-Lessard P, Chollet JF et al. Antifungal effects of salicylic acid and other benzoic acid derivatives towards Eutypa lata: structure-activity relationship. Plant Physiol Biochem 2002; 40: 1051-1060.

39 Faleiro ML, Miguel MG, Ladeiro F et al. Antimicrobial activity of essential oils isolated from Portuguese endemic species of Thymus. Lett App/ Microbio/ 2003; 36(1): 35-40.

40 Ultee A, Bennik MH, Moezelaar R. The phenolic hydroxyl group of carvacrol is essential for action against the food-borne pathogen Bacillus cereus. Appl Environ Microbiol 2002; 68: 1561-1568.

(c) This work is licensed under a Creative Commons Attribution-NonCommercial-NoDerivative Works 3.0 Unported License. To view a copy of this license, visit http:// creativecommons.org/licenses/by-nc-nd/3.0 